\title{
The goals of the National Biodiesel Program: between planning and implementation
}

\author{
Gean Claudio de Souza Santana
}

${ }^{I}$ Full professor at the State University of Feira de Santana, Uefs, Feira de Santana, Bahia, Brazil.

\begin{abstract}
This work evaluated whether the main goals established by the National Program for the Production and Use of Biodiesel (PNPB) were achieved between 2004 and 2018. For this purpose, reports and surveys prepared by public agencies and soybean producers were used. The results reveal that expectations of improvement in living conditions in rural areas stemming from PNPB implementation were frustrated: there were job losses in agricultural occupations, continuity of rural exodus, increase in land concentration, reduction in the contingent of family farmers, non-inclusion of poor family farmers from the North and Northeast regions. Of the original PNPB goals, only the minimum percentage of biodiesel to diesel was achieved satisfactorily, but dependence on imported diesel increased, even with the development of biodiesel production.
\end{abstract}

Keywords: Biodiesel; biofuel; family farmers; Social Fuel Seal; PNPB.

São Paulo. Vol. 24, 2021

Original Article

DOI: http://dx.doi.org/10.1590/1809-4422asoc20200088r2vu2021L5AO 


\section{Introduction}

Biofuels are a response to worldwide unease concerning global warming, environmental pollution and the damaging effects on human health stemming from the intensive use of fossil fuels. However, it is not possible to generalize and state that the biofuel production chain has only beneficial impacts. In some east Asian, Latina American and Caribbean countries, for example, increased demand for biofuel has actually led to an increase in greenhouse gas emissions (ZAMAN et al., 2016; BARR et al., 2021). Tropical forests in Malasia and Indonesia have been devastated to make way for the expansion of oil palm (Elaeis guineenses) plantations and meet the European Community's demand for vegetable oil to supply its biodiesel industries. It is estimated that each hectare of destroyed forest liberates 174 tons of carbon dioxide (CO2) (BARR et al., 2021). In the United Staes, even though the production of ethanol from maize has guaranteed rural economic development, increased employment and reduced fossil fuel consumption, the following impacts have been detected: pollution and water shortages, soil degradation, biodiversity loss, increase in atmospheric pollutants, and greater food insecurity (HOEKMAN et al., 2018). In Romania the prices of some important food products such as wheat, sunflower, oats and soybean have gone up because of the change in land use to plant oil bearing crops too supply biodiesel production (VASILEA et al., 2016). In 2006 and 2007 sudden increases in the price of maize sparked grassroots revolts in Mexico and other parts of Latin America (BARR et al., 2021). Berger et al. (2015) found that the biodiesel production chain in Europe consumes 60 times more water than the gasoline production chain. In Brazil, the logic of biodiesel production has contributed to the expulsion of traditional and peasant communities from their lands to make way for the expansion of soybean, and sugar cane crops and cattle raising (SILVA, 2008; RAMOS FILHO, 2015).

The creation of the National Biodiesel Program (Programa Nacional de Produção $e$ Uso do Biodiesel - PNPB) was an innovation on the biofuel agenda because for the first time an effort was made to 'tie' social objectives to an energy policy from the perspective of the social inclusion of vulnerable farmers (BARCELOS, 2015; SILVA, 2018; STATTMAN; MOL, 2014; RODRIGUES, 2021) and the eradication of extreme poverty from the Brazilian rural milieu. Such objectives "had been left out of the formulations for more than 30 years in the context of bio-energy policies in Brazil" (BARCELOS, 2015, p.8). On the other hand, Locatel and Azevedo (2008) considered that providing incentives to family farmers to supply raw materials for the biodiesel industry does not, of itself, make the program a 'social program nor does it make the biodiesel a 'social fuel'; it may actually lead the farmers into a process of total submission to the interests of the refinery owners, converting the farmers into mere agroindustry labor power as has happened in similar experiences in Brazil that those authors have studied.

Against that background, this study aims to seek the answers to certain questions, namely: has there been a reversal of the tendency to the reduction of rural populations and a stabilization of people in the rural environment with a consequent increase in the number of family farmers, in the wake of PNPB implantation? In regard to agricultural occupations and land holding concentration: have they increased or decreased? Which 
of the main PNPB goals have been achieved? To endeavor to find the answers to those questions, this research study gathered information using materials elaborated by the Brazilian Geography and Statistics Institute (Instituto Brasileiro de Geografia e Estatística - IBGE), the National Petroleum, Natural Gas and Biofuels Regulatory Board (Agência Nacional do Petróleo, Gás Natural e Biocombustíveis - ANP), vegetable oil producers associations, and various other bodies, institutions and entities, as well as retrieving some important contributions made by researchers in this field.

\section{The National Biodiesel Program (PNPB), the Social Fuel Seal and changes in the legislation}

The Brazilian Federal Government created the National Biodiesel Program (PNPB) in 2004 with the aim of organizing the production chain, establishing lines of finance, structuring the technological base and editing the biodiesel regulatory framework. Among the various official documents addressing the Program objectives the most outstanding is entitled 'Biodiesel and Social Inclusion' (HOLANDA, 2004), elaborated by the House of Representative's Special Council for Higher Studies and Economic Assessment (Conselho de Altos Estudos e Avaliação Econômica), resulting from a videoconference held in November 2003 with the participation of Ministers of State, businessmen, researchers from Brazilian research centers, and members of non-governmental organizations. Prior to the creation of the PNPB there had been other initiatives endeavoring to make biodiesel a viable alternative to diesel (CAVALCANTE FILHO et al., 2019; SAMPAIO, 2017; BARCELOS, 2015; COSTA, 2017).

The original PNPB design "planned to involve 200 thousand small farmers in the first years of its implementation, setting priority on poor farming families in the less developed regions of the country with acknowledged concentrations of extreme rural poverty" (SILVA, 2018, p. 2) and adopting castor oil and palm oil as the main raw materials (RODRIGUES, 2021). It favored planting in consortia to maintain an equilibrium between energy and food, and to reduce the importation of diesel; its immediate impact was expected to be a reduction of hard-currency losses with the importation of diesel.

To ensure that the PNPB fulfilled its social inclusion and regional development goals, a Social Fuel Seal (Selo Combustivel Social - SCS) was instituted by Decree 5.297 in 2004. The Decree (BRASIL, 2004) determined that the Seal would be awarded to those biodiesel suppliers who purchased a minimal percentage of their raw materials from family farmers classified as such in the terms of the National Family Agriculture Program (Programa Nacional de Agricultura Familiar - PRONAF) or from its cooperatives. In addition to acquiring that minimum percentage, the biodiesel producer had other obligations such as: pre-establishing raw material sale and purchase contracts negotiated with family farmers or their respective cooperatives, with the consent of the State or Municipal family agriculture entities, and provision of capacity-building and technical assistance for the contracted farmers. The concession of the right to use the Federal Government-regulated Seal allows the biodiesel producer to pay smaller aliquots of the taxes on commercialized biodiesel and to participate in reserved blocks in the biodiesel trading auctions (SILVA 
E SILVA et al., 2017). According to Brasil (2009) the minimum percentage is defined by the following equation:

$$
\text { minimum percentage }=\mathrm{X} / \mathrm{Y} \times 100
$$

Where $Y$ represents the sum of the values, in Brazilian reals, of the total annual acquisitions of raw materials in the period of biodiesel production;

$\mathrm{X}$ represents the annual cost, in Brazilian reals, of acquisitions of raw materials from family farmers.

With the aim of reducing the idle capacity of the installed industries, the obligatory inclusion percentages of biodiesel in diesel were gradually anticipated until they attained the current level of $12 \%$. In view of the non-regionalization of raw material production and the low level of social insertion, the minimal percentage requirements for raw material acquisition from family agriculture sources were altered by regions: the minimum requirement for the Northeast Region was reduced from $50 \%$ to $30 \%$; for the Region South, it was raised from 30\% to 40\% and for the Central-western and Northern regions it was raised from $10 \%$ to $15 \%$.

Initially only the purchase cost of the raw materials constituted the value of X. After the modification of the legislation, however, other costs were allowed to be included and added to the overall annual cost registered for the acquisition of the raw materials, that is, the value of $\mathrm{X}$ in equation (1). Those additional costs are: capacity building and technical assistance provision, soil analysis, agricultural inputs, expenses with research for the diversification of the raw materials produced by family agriculture. Under pressure from the biodiesel producers (SILVA, 2019), other alterations were made to the legislation so that the role of the Social Fuel Seal was completely reversed and it actually contributed to the virtual inflation of costs associated to the acquisition of raw material from family agriculture making it easier to attain the minimal percentage for obtaining the Seal, favoring the oil mills with the associated tax exemptions, guaranteeing their participation in the public biodiesel auctions (SILVA e SILVA et al., 2017, CAVALCANTE FILHO, 2020) and serving as a strategy for legitimizing the benefits accruing to the factories that were awarded the Social Fuel Seal (SILVA, 2018).

\section{Evaluations of the PNPB}

Nery do Prado (2015) considers that the PNPB was created as a solution to get rid of the excess of soybean oil in Brazil which had a very large stock in the early years of the 2000 decade. According to that author, in a similar way to the situation of some European countries that had an excessive stock of rapeseed oil, biodiesel production in Brazil was seen as an alternative for draining off the excess of soybean oil. However, in no part does the PNPB state that it was created to address the exaggerated stock of soybean oil in Brazil, not even partially. There was an explicit concern that the biodiesel should be produced from a variety of oil-bearing species and in that way include in the biodiesel production chain small-scale farmers with experience with other species of oil-producing plants such as castor oil bean and oil palm. The reports of the Brazilian Association of 
Vegetable Oil Industries (Associação Brasileira das Indústrias de Óleos Vegetais - Abiove) (2020) show that initial and final stocks of soybean meal and soybean oil remained even over the period 2000 to 2018: around a million tons of meal and 300 thousand tons of oil. Furthermore, the initial and final stocks of soybean bean in natura also remained even with the exception of the year 2003 when the initial stock was 3.33 million tons and the final stock was 7.19 million tons. In 2003, discussions of PNPB implantation took place in the sphere of the Federal Executive branch, in the parliament and in civil society at large. It is possible that the sudden variation referred to was the consequence of the great expectation of an increased demand for soybean. However, it can be seen from the numbers presented above that the PNPB did not alter the situation of Brazil's soybean oil or meal stocks in any way.

Contrary to initial Program expectations, family farmers in Brazil's Southern and Central-western macro-regions ended up having a far larger participation in the biodiesel production chain to the detriment of the farmers in the Northern and Northeastern regions (CÉSAR; BATALHA, 2013; STATTMAN; MOL, 2014; CÉSAR et al., 2019; DE OLIVEIRA et al., 2019; SILVA, 2019). Certain factors enable an understanding of why that situation came about, namely: a) the control of soybean production that is in the hands of large corporation's located in the Brazilian South and Central-west; b) a greater degree and tradition of associative organization that exists among the family farmers of the Southern and Central-Western regions; c) the easier access of these Southern and Central-Western family farmers to rural credit, agricultural inputs and other agricultural equipment; d) the proximity of the large-scale soybean producers and the biodiesel industries (LEITE et al., 2015; DE OLIVEIRA et al., 2019; CÉSAR; BATALHA, 2010; CÉSAR et al., 2019).

The structure of Brazilian land tenure patterns, indelibly marked by the unequalness of land ownership, has also constituted an obstacle to the insertion of small-scale farmers in the hegemonized markets of agribusiness (DE OLIVEIRA et al., 2019; CAVALCANTE FILHO, 2020; HOFFMANN; SANTOS, 2020). The characteristic, centuries old, highly unequal distribution of land tenure in Brazil is another characteristic correlated with the lower levels of human development in the country's microregions (HOFFMANN; JESUS, 2020).

As regards castor oil bean, certain factors were important in determining that it did not become a raw- material option for biodiesel production, namely: the high viscosity of castor oil diesel which damages engines; 2) the demand of the chemical industry that uses castor bean oil for other purposes and ends up elevating its price; and 3) the superior availability of other sources such as soybean oil and bovine suet which makes them more competitive than castor bean oil (MEDINA, 2008; FREITAS, 2010; SANTANA et al., 2010; DE OLIVEIRA et al., 2019; RODRIGUES, 2021).

Regarding the effects of the biodiesel production chain on Brazilian family agriculture, Cavalcante (2002) concluded that, as yet little was known. In the view of Costa (2017) and Castro Mur (2019), however, the main merit of the Program in the aspect of inserting the small-scale farmers in the biodiesel production process has been the genera- 
tion of employment and income. Ribeiro and Dias (2015) evaluated the gains obtained by small-scale farmers who supply soybean to the biodiesel producers and found that even in the settlements a considerable part of the income is appropriated by capital because the seed and inputs purchases are what weigh heaviest in soybean cultivation. Again according to Ribeiro and Dias (2015), as the effect of the Social Fuel Seal is to ensure a guaranteed market for soybean produced by family agriculture, the Program makes the families the targets of dispute among the private companies such as the stores that finance the sales of agricultural inputs and the companies that trade in grains and/or produce biodiesel. In the states of Piauí, Sergipe and Goiás, farmers have been obliged to stop planting food crops because of the pressure from the biodiesel and alcohol mill owners (SILVA, 2018; RAMOS FILHO, 2015; RESENDE, 2015).

In spite of the admitted fragility of the diversification of raw materials, the Federal Government assessment of the PNPB after 10 years of its existence (BRASIL, 2015) showed that: 42 of the 51 biodiesel-producing factories possessed the Social Fuel Seal; there had been steady growth in the average income of family farmers benefitted by the Social Fuel Seal scheme; the number of cooperatives supplying raw materials and expenditure on technical assistance and promotion in the ambit of the Social Fuel Seal had increased; the Social Fuel Seal benefitted family farmers in 14 states and 1,001 municipalities, and $30 \%$ of the raw material supply came from family agriculture, all of which Bosi (2015) considered to be palpable inclusion results despite the fact that most of the family farmers were in the Southern and central-western macro-regions. Silva $(2018$, p.5) underscores that "the alterations to the SFS drew the family farmers away from the social aspect of the PNPB transforming it into a monocropping program with regional centralization".

\section{Materials and methods}

Based on the objectives of the National Program for the Production and use of Biodiesel, the study gathered information and data to evaluate the extent of accomplishment of the goals. The data used to evaluate the PNPB were: variations in the populations residing in the urban milieu and the rural milieu; agricultural and non-agricultural occupations; the number of rural establishments and their total area; evolution of the number of family farmers, the areas planted with soybean, other oil-bearing crops and food crops; and characterization of the raw materials used for biodiesel production. The data were obtained for the period between 2004 and 2018 with the exception of the data on the evolution of the rural and urban populations for which this research used the data of the last National Household Sample Survey (Pesquisa Nacional por Amostra de Domicílios - Pnad) carried out in 2015.

Data sources were as follows: the 2010 Demographic Census, the 2006 and 2017 Agriculture Censuses, the Pnad and Continuous Pnad and the Municipal Agriculture Survey (Pesquisa Agrícola Municipal - PAM) conducted by the IBGE; the ANP; the Abiove monthly reports, and the National Energy Balance document (Balanço Energético Nacional - BEN) elaborated by the Energy Research Company (Empresa de Pesquisa Energética - EPE). 


\section{Results - presentation and discussion}

\section{Biodiesel and raw materials production}

Table 1 shows that 41 companies produced 5,350 thousand $\mathrm{m}^{3}$ of biodiesel in 2018: the states of Paraná, Rio Grande do Sul, Mato Grosso and Goiás were responsible for $74 \%$ of national production. The distribution by macro-regions of the accumulated production for the period between 2006 and 2018 was: North $-2.0 \%$, Northeast $-8.2 \%$, Southeast $-10.0 \%$, South $-37.4 \%$ and Central-west $-42.4 \%$. The macro-regions North and Northeast produced a mere $19 \%$ of the biodiesel thereby revealing the low degree of insertion of those regions in the biodiesel production chain.

To meet biodiesel production needs, in 2018, 5,304 thousand $\mathrm{m}^{3}$ of animal fats and vegetable oils were supplied to biodiesel industries in the following proportions by class of raw material: $70 \%$ soybean oil, $16 \%$ animal fats, $1 \%$ cotton seed oil, $2 \%$ of used frying oil and 16\% of other fatty materials. Between 2006 and 2018, the distribution of raw materials supplied to meet biodiesel production demands was: soybean $-76.6 \%$, animal fats $-16.6 \%$, cotton seed oil $-2.0 \%$ and other fatty materials $-4.8 \%$.

Table 1 - Biodiesel in 2018: number of authorized companies, installed capacity and production. Family agriculture supplied raw materials: in 2018 and accumulated percentage between 2008 and 2018

\begin{tabular}{|c|c|c|c|c|c|}
\hline State & $\begin{array}{l}\text { Number of } \\
\text { authorized } \\
\text { production } \\
\text { companies }\end{array}$ & $\begin{array}{l}\text { Installed } \\
\text { biodiesel } \\
\text { production } \\
\text { capacity } \\
\left(\mathrm{m}^{3} / \text { month) }\right.\end{array}$ & $\begin{array}{l}\text { Biodiesel } \\
\text { production } \\
\left(\mathrm{m}^{3}\right)\end{array}$ & $\begin{array}{l}\text { Family agri- } \\
\text { culture raw } \\
\text { materials } \\
\text { for biodiesel } \\
\text { production } \\
\text { (thousand } \\
\text { tons) }\end{array}$ & $\begin{array}{l}\text { Family agri- } \\
\text { culture raw } \\
\text { materials } \\
\text { for biodiesel } \\
\text { production as } \\
\text { a percentage of } \\
\text { accumulated } \\
\text { national total } \\
\text { for the period } \\
\text { between } 2008 \\
\text { and } 2018(\%)\end{array}$ \\
\hline Rondônia & 1 & 32,850 & 16,232 & 2.46 & 0.01 \\
\hline Tocantins & 2 & 321,565 & 85,107 & - & 0.12 \\
\hline Piauí $^{1}$ & 1 & 91,250 & - & - & 0.00 \\
\hline Ceará $^{2}$ & 1 & 18,250 & - & - & 0.06 \\
\hline Bahia & 2 & 600,592 & 376,338 & 41.92 & 0.69 \\
\hline Minas Gerais & 1 & 169,228 & 127,946 & 13.18 & 0.53 \\
\hline
\end{tabular}

1- The biodiesel company installed in the state of Piauí produced biodiesel up until 2010.

2. The biodiesel company installed in the state of Ceará produced biodiesel up until 2017. 


\begin{tabular}{l|l|l|l|l|l}
$\begin{array}{l}\text { Rio de Ja- } \\
\text { neiro }\end{array}$ & 2 & 225,095 & 96,103 & - & 0.00 \\
$\begin{array}{l}\text { São Paulo } \\
\text { Paraná }\end{array}$ & 4 & 482,409 & 233,653 & 30.15 & 2.46 \\
$\begin{array}{l}\text { Santa Cata- } \\
\text { rina }\end{array}$ & 1 & 807,745 & 597,348 & 736.52 & 13.50 \\
$\begin{array}{l}\text { Rio Grande } \\
\text { do Sul }\end{array}$ & 8 & 186,150 & 122,131 & 230.40 & 4.83 \\
$\begin{array}{l}\text { Mato Grosso } \\
\text { do Sul }\end{array}$ & 2 & $2,457,665$ & $1,479,467$ & $2,47.93$ & 59.35 \\
Mato Grosso & 17 & 474,500 & 324,483 & 123.9 & 3.68 \\
Goiás & 6 & $2,187,613$ & $1,133,560$ & 38.67 & 4,25 \\
Brasil & 50 & $1,277,500$ & 757,669 & 220.97 & 10.10 \\
\hline
\end{tabular}

Source: ANP, 2019; Brasil, 2019.

\section{Family agriculture participation and the expansion of oil-bearing crops}

As Table 1 shows, in 2018, family agriculture supplied the biodiesel-producing companies with 3,820 thousand tons of oil-bearing raw materials from which 841 thousand $\mathrm{m}^{3}$ of oil were extracted. That supply represents $15.84 \%$ of all the raw material used for biodiesel production in that year. According to Brazilian data (Brasil, 2019) in the period between 2008 and 2018, the family agriculture supply discriminated by macroregions was: North $-0.46 \%$, Northeast $-0.84 \%$, Southeast $-2.99 \%$, South $-77.68 \%$ and Central-west $-18.03 \%$ confirming the observations of Silva (2019), Silva and Silva et al. (2017) and IPEA (2012) regarding the alterations to the Social Fuel Seal legislation. Those authors state that the alterations made to the conditions for awarding the Social Fuel Seal favored the biodiesel producers, inflated the costs of obtaining raw material from family farmers and entirely subverted the role of the SFS. Indeed, the percentage of oil that has its origins in family agriculture raw materials, $14.7 \%$, is well below the $40 \%$ minimum specified in the SFS concession regulations for macro-region South. In the period between 2008 and 2018, the South was responsible for almost $80 \%$ of all the raw material supplied to the biodiesel producers. Furthermore, macro-regions North and Northeast are hardly inserted in the biodiesel production chain at all: between 2008 and 2018 their family farmers suppled a mere $1.34 \%$ of the total family agriculture raw material and between 2006 and 2018 their biodiesel production corresponded to $10.2 \%$ of the national production.

As regards the areas dedicated to soybean crops, to other oilseed crops and to crops essentially for food supply, it can be seen from Graph 1 that there was an expansion in the first-mentioned, stagnation in the second and a reduction in the third. The area used for soybean crops increased $61.2 \%$ between 2004 and 2018. The area dedicated to cotton,

3 - The biodiesel company installed in the state of Santa Catarina produced biodiesel up until 2013. 
oil palm and castor bean increased by $0.62 \%$ while the area devoted to food crops other than oil bearing plants decreased by $18.5 \%$. Again, in that period, soybean production increased $138 \%$ whereas production of beans, rice and manioc (cassava) diminished 1.7\%, $11 \%$ and $25 \%$ respectively.

The data of Abiove (2020) show that soybean grain harvests increased $145 \%$ between 2004 and 2018. In 2019, the harvest was 123,081 thousand tons of soybean grain of which $60 \%$ was exported in natura and $36 \%$ processed internally to produce soybean meal and oil. Again according to Abiove (2020), in 2004 Brazil exported about 40\% of its soybean production in natura and processed the rest. The inversion of that relationship occurred in 2012 when Brazil began to export more soybean than it processed internally.

Between 2004 and 2018, the area dedicated to the soybean crop increased $61.2 \%$ : in 2004, 21,601 thousand hectares were planted whereas in 2019 the area was 34,838 thousand hectares. In 2018, the biodiesel industries consumed 3,363 thousand tons of soybean oil (ABIOVE, 2020; ANP, 2019). Considering that the percentage of oil in a grain of soybean is around 20\% (ABIOVE, 2020), then there must have been a supply of approximately 16,815 thousand tons of soybeans to meet the biodiesel industries' demand in 2018. Given that the average yield of soybean in 2018 was $3,390 \mathrm{~kg} / \mathrm{ha}$ (IBGE, 2021), then the area planted to supply the biodiesel demand alone was 4,969 thousand hectares in 2018, that is, $23 \%$ of the increase in the planted area compared to 2004 was to meet the biodiesel demand in 2018, corresponding to $37.5 \%$ of total growth in cultivated area over the period.

Thus it can be concluded that the expansion of the cultivated area and the increase in soybean production between 2004 and 2018 were not the consequence of the PNPB. That means other factors such as the international market, which absorbs a considerable part of the soybean production, drove the soybean expansion. In 2018, 79\% of soybean production was exported in the form of soybean meal or oil or in natura. Between 2004 and 2018 the lowest percentage exported was $70.8 \%$, in 2010. 
Graph 1 - Evolution of areas planted with food crops, with soybean and with cotton oil palm sunflower and castor oil bean

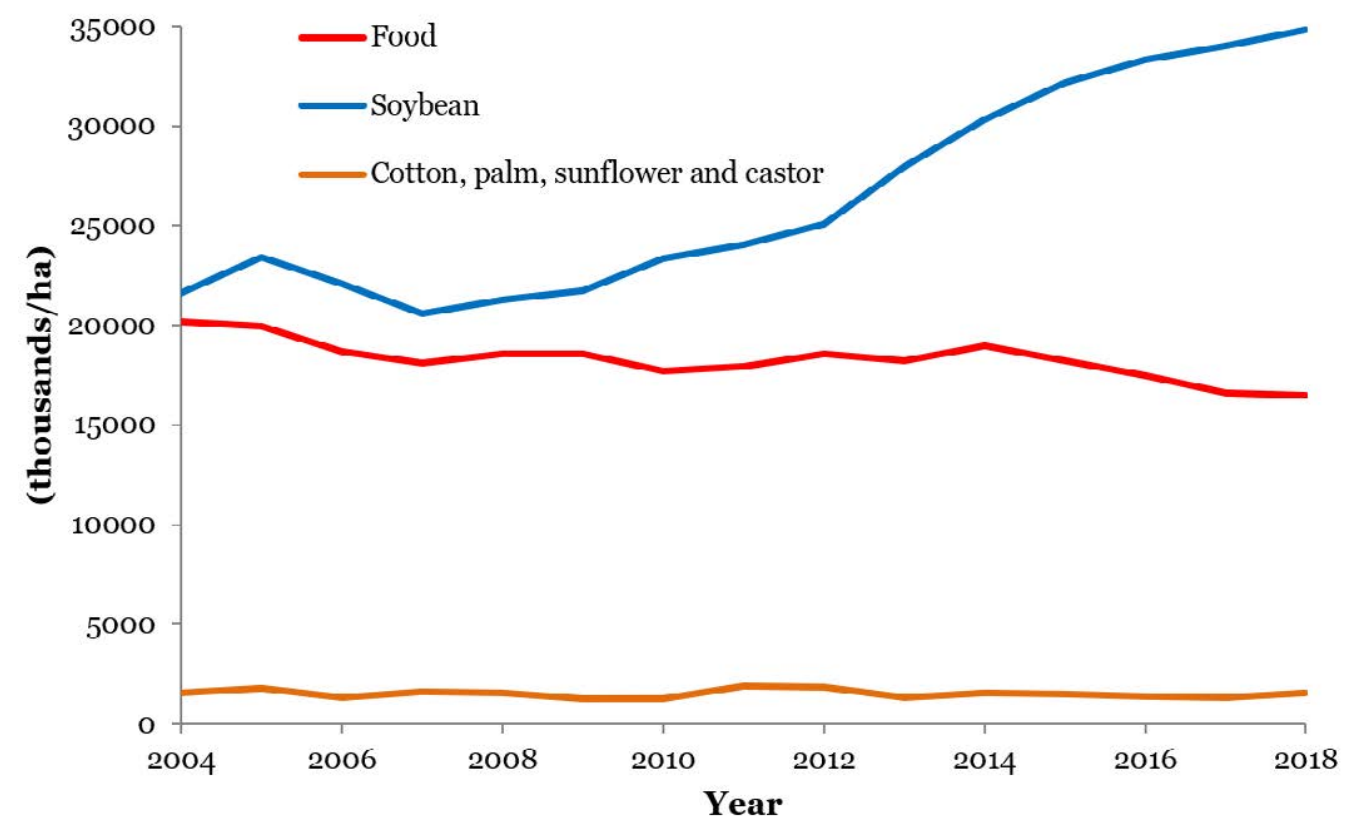

Source: IBGE, 2021.

In the case of family agriculture, between 2006 and 2017, according to the data of the Agricultural Census for the years 2006 (IBGE, 2006) and 2017 (IBGE, 2017), there was reduction not only in the planted area but also in the amount harvested of the main Brazilian food crops, namely, beans, rice and manioc (cassava). The drop in the production of those food items was $60 \%$ and family agriculture participation in national production of them fell from $62 \%$, in 2006 , to $24 \%$ in 2017 . Thus family agriculture was no longer the main supplier of those food items for the tables of the Brazilian people. In the South and Central-West macro-regions the drops in production were of 39\% and $35 \%$, respectively. In the same period soybean production increased $40 \%$ in the South and $75 \%$ in the Central-West. Actually, even prior to the PNPB, bean crops were making way for commodities like soybean, maize and sugarcane given the possibility of obtaining higher prices and profits and the existence of market stability (BINI; CANEVER, 2015), and despite the risks of food insecurity (CORRÊA et al., 2019; RIBEIRO et al., 2017; PIRAS et al., 2021). Even if the PNPB cannot be considered the main factor responsible for those alterations, because only a little over $30 \%$ of family agriculture-produced soybean in the southern and central-western regions is destined for the biodiesel refineries, it has indubitably contributed to farmers decision to replace crops like beans, rice and manioc with soybean. In the state of Sergipe, for example, Ramos Filho (2015) verified that periods when that state's sugar/alcohol sector began to decline, with a fall in the areas of planted and harvested sugarcane, coincided with an increase in the planting and production of food crops thereby highlighting the subjacent competition of the food production system 
and the agrofuel system and the changes in land use. In turn the PNPB creates expectations in the farmers that they will be inserted in new markets and expand their chances of accessing agricultural credit policies activating their properties financially (SILVA, 2019). In their relation with the biodiesel plant owners, they lose their food producing autonomy because of the pressure from the biodiesel producers (QUEIROZ; GARCIA, 2015, RAMOS FILHO, 2015; SILVA, 2019, LOCATEL; AZEVEDO, 2008).

\section{Diesel importation after the PNPB}

One of the economic arguments for introducing biodiesel into the Brazilian energy matrix was that Brazil imported diesel. By producing biodiesel, the country would stop spending on importing diesel and the currency saved could be invested in the PNPB (HOLANDA, 2004). However, in recent years, dependence on imported diesel has been increasing. In 2004 Brazil imported 2.7 million liters but by 2019 the figure was up to 11.6 million liters according to data of the ANP (2019) and EPE (2019). In addition to the increase in domestic consumption of diesel, the decrease in Brazil's own production is another factor that has led to an increase in diesel importation.

\section{Keeping people in rural areas and employment created in the period}

An evaluation of the size of the rural population reveals that, generally speaking and in consonance with the 2010 Demographic Census (IBGE, 2011) and the Pnad (IBGE, 2015) the tendency is to a reduction, passing from $15.4 \%$ in 2004 to $13.9 \%$ in 2015 - a reduction of $9.7 \%$. In the main biodiesel producing states, for the period between 2004 and 2015 the reduction in percentages of the overall population residing in rural areas were: Bahia $-26.0 \%$ to $20.5 \%$; Paraná $15.6 \%$ to $13 \%$; Rio Grande do Sul $-14.1 \%$ to $10.1 \%$; Mato Grosso do Sul $-14.6 \%$ to $10.1 \%$ Mato Grosso $-23.2 \%$ to $18.3 \%$; Goiás $14.0 \%$ to $8.6 \%$.

Those results may be related the comparative advantages of the urban milieu over the rural which persisted in the period under study, and among which are occupations and public services such as education, health transportation and leisure. However precarious living conditions may be in the cities, the public services offer is still far greater than in the countryside or the rural milieu at large. Thus, generally speaking there was no inflection of the descending curve representing the population residing in rural areas after implantation of the National Program for the Production and use of Biodiesel, quite the contrary; the rural exodus continued emptying the countryside of people and swelling the cities with them.

Another important piece of information concerns the area occupied per agricultural establishments, where the tendency indicates an increasing concentration of land tenure. Data of the Agricultural Censuses for 2006 (IBGE, 2007) and 2017 (IBGE, 2017) show that the number of establishments in 2006 was 5.176 million, occupying an area of 333.68 million hectares; that means an average of 64 hectares per establishment. By 2017, however, the number of establishments had fallen to 5.073 million while the area they 
occupied was 351.29 million hectares; that is an average of 69 hectares per establishment. The Gini index which serves to indicate the degree of inequality in land holding went from 0.8652 to 0.8666 , that is, it remained practically unaltered for the period between 2006 and 2017. The pattern of the area/establishment (hectares /establishment) and the Gini index of the main biodiesel producing states are set out in Table 2 below.

Table 2 - Occupied area per establishment and Gini index records for the Years 2006 and 2017 of the main biodiesel-producing states

\begin{tabular}{l|ll|ll}
\hline \multirow{2}{*}{ State } & \multicolumn{3}{|l|}{$\begin{array}{l}\text { Area/establishment (hectares/ } \\
\text { establishment) }\end{array}$} & Gini Index \\
\cline { 2 - 5 } & 2006 & 2017 & 2006 & 2017 \\
\hline Bahia & 39 & 37 & 0.8458 & 0.8518 \\
Paraná & 41 & 48 & 0.7769 & 0.7930 \\
Rio Grande do Sul & 46 & 59 & 0.7783 & 0.7924 \\
Mato Grosso do Sul & 467 & 429 & 0.8566 & 0.8673 \\
Mato Grosso & 431 & 463 & 0.8666 & 0.8755 \\
Goiás & 193 & 173 & 0.7827 & 0.7889 \\
Brazil & 64 & 69 & 0.8652 & 0.8666 \\
\hline
\end{tabular}

Source: IBGE, 2007; IBGE, 2020a.

The above results of the 2006 and 2017 Agricultural Censuses show that there was almost no alteration to the land tenure structure over the period in spite of a slight tendency to worsen inequality and land tenure concentration. The reduction in the average area per establishment in the states of Mato Grosso and Goiás may be associated to the increase in the number of smallholdings and other small properties destined for leisure and weekends/holiday occupation as Hoffmann and Jesus (2020) have identified in similar situations. The data from the earlier Agricultural Censuses from 1975 to 2006 had already revealed the great stability of inequality in the distribution of land tenure throughout Brazil and that was further confirmed by the results of the Agricultural Census of 2017 (HOFFMANN; JESUS, 2020).

As regards the contingent of persons engaged in agriculture activities, in nonagricultural activities and in family agriculture between 2004 and 2018, this study gathered micro-data from the National Household Sample Survey (IBGE, 2015) and the Continuous National Household Survey (IBGE, 2020b). For estimate calculation, the population engaged in such activities aged 14 or over was considered. The data reading was achieved using a program in Stata made available to the study by the Catholic University of Rio de Janeiro. Table 3 displays the results for variations in the contingents of persons occupied in agricultural and non-agricultural actives and in family agriculture between 2004 and 2018 in the main biodiesel producing states. 
Table 3 - Variations in the numbers of persons aged 14 or over occupied in agricultural, non-agricultural and family agriculture activities between 2004 and 2018 in the main Brazilian biodiesel-producing states

\begin{tabular}{|c|c|c|c|c|}
\hline \multirow[b]{2}{*}{ State } & \multicolumn{2}{|c|}{$\begin{array}{l}\text { Variations in the num- } \\
\text { bers of persons engaged } \\
\text { in }\end{array}$} & \multirow{2}{*}{$\begin{array}{l}\text { Variations } \\
\text { in the } \\
\text { numbers } \\
\text { of jobs in } \\
\text { agriculture } \\
\text { with or } \\
\text { without } \\
\text { labor con- } \\
\text { tracts }\end{array}$} & \multirow{2}{*}{$\begin{array}{l}\text { Variations in } \\
\text { the numbers } \\
\text { engaged in } \\
\text { Family agri- } \\
\text { culture (\%) }\end{array}$} \\
\hline & $\begin{array}{l}\text { Agricultur- } \\
\text { al activities } \\
(\%)\end{array}$ & $\begin{array}{l}\text { Non- ag- } \\
\text { ricultural } \\
\text { activities } \\
(\%)\end{array}$ & & \\
\hline Rondônia & -42.1 & 0.8 & 2.9 & -51.2 \\
\hline Tocantins & -55.2 & 16.6 & -39.0 & -62.8 \\
\hline Ceará & -57.9 & 6.1 & -7.6 & -48.0 \\
\hline Bahia & -61.1 & 5.8 & -42.1 & -55.3 \\
\hline Minas Gerais & -45.0 & 20.5 & -25.5 & -35.5 \\
\hline Rio de Janeiro & -28.5 & 28.7 & -21.7 & -27.2 \\
\hline São Paulo & -32.7 & 38.6 & -30.1 & -28.6 \\
\hline Paraná & -47.7 & 11.0 & -26.3 & -42.0 \\
\hline Santa Catarina & -50.7 & 19.6 & -46.5 & -50.6 \\
\hline Rio Grande do Sul & -46.2 & -1.1 & -0.7 & -39.6 \\
\hline Mato Grosso do Sul & -60.9 & 25.5 & 31.6 & -20.3 \\
\hline Mato Grosso & -57.1 & 29.5 & -25.0 & -42.4 \\
\hline Goiás & -46.7 & 37.8 & -10.4 & -28.2 \\
\hline Brasil & -59.5 & 23.9 & -32.5 & -48.8 \\
\hline
\end{tabular}

Source: IBGE, 2015; IBGE, 2020b.

In all the biodiesel-producing states there was a reduction in agricultural occupations consistent with national rhythm of the reduction of $57.9 \%$. The states of Bahia and Mato Grosso do Sul had smaller reductions than the national average. In regard to nonagricultural occupations, all the biodiesel-producing states presented a positive variation except Rio Grande do Sul which showed a slight drop of $1.1 \%$. As for the contingent of those engaged in family agriculture there was a reduction in all the biodiesel-producing states consistent with the national tendency to reduction. In regard to employment in agricultural occupations with or without a formal labor contract, only the states of Mato Grosso do Sul and Rondônia registered generation of employment with increases of $31.6 \%$ and $2.9 \%$ respectively. Even so, they registered an overall decrease in the numbers of agricultural occupations and of those engaged in family agriculture. Furthermore, those two states have very little participation in national biodiesel production and in the supply of raw materials coming from family agriculture for biodiesel production. 
In their study of inequality in Brazilian agriculture, Hoffmann and Santos (2021) identified: a) a tendency to reduction in the number of people engaged in agricultural activities in comparison with the total number of people with occupations: participation fell from $16.3 \%$ in 1995 , to $8.2 \%$ in 2019 ; b) greater inequality and lower average income among agricultural occupations compared to non-agricultural ones: average income from agricultural occupations was only 50 to $60 \%$ of the average income from non-agricultural occupations over the period between 2001 and 2019. That means the poverty levels in the agricultural sector were more than three times higher than in the non-agricultural sector: c) that although there had been a reduction of inequality in income distribution among the economically active population (população economicamente ativa - PEA) and among those engaged in non -agricultural activities, in the agricultural occupations, inequality remained stable between 2001 and 2015 with an increase between 2009 and 2013. The results that Hoffmann and Santos (2020) obtained show that land ownership is a fundamental element for enabling an understanding of that pattern among the agricultural occupations.

Regarding place of residence, whether rural or urban, the situation is as follows: in $2004,8 \%$ of the population engaged in non-agricultural activities lived in rural areas; by 2018 , the percentage had gone up to $10 \%$. In the case of people engaged in agricultural activities, 70\% lived in rural areas in 2004 and 2018. It is possible that part of the contingent that lost their jobs in agricultural activities migrated to non-agricultural activities but opted to continue living in the rural areas.

The above results fail to confirm the generation of employment by the PNPB that Costa (2017) and Castro Mur (2019) referred to in their work: there was a reduction in agricultural occupations and in employment in agricultural occupations in all the biodieselproducing states except Mato Grosso do Sul and Rondônia with the abovementioned reservations regarding these last two states. The conclusions of a study conducted by the DIEESE $(2014$, p. 9) reinforces the results of the present research stating that "there may be a migration in course of small scale producers with very poor economic conditions to a subsistence situation while at the same time the large landholdings advance over the small ones", thereby reducing any possibility of the vulnerable family farmers inserting themselves in the market and trading their products.

On the other hand, the work of Hoffmann and Santos (2020) contributes to a better understanding of what is behind that situation: ownership of the land influences the possibility of accessing agricultural credit and consequently financing the acquisition of agricultural equipment and inputs. The results of the Agricultural Censuses show that land tenure structure in Brazil has remained stable over time with a tendency to further concentration and an increase in inequality. The work of those two authors also elucidates why the PNPB's original proposals to generate employment, promote the inclusion of small-scale farmers in the most impoverished regions of the country and diversify the raw materials destined for biodiesel production have not been achieved; in other words, why the PNPB was insufficient to achieve the goals that it established for itself. On the other hand, further studies are necessary to assess the PNPB's real contribution to maintaining 
the above-described situation in the countryside and why it was insufficient to achieve the social objectives that were established at the beginning, apart from the aspects delineated in the present study.

\section{Conclusions}

The PNPB gave rise to expectations that after its implementation, there would be generation of employment in the rural milieu, inclusion of vulnerable small farmers and Brazil's least developed regions, a reduction of the rural exodus and of land tenure concentration and consequently an overall improvement in rural living conditions. However, the results set out in this article reveal that those expectations have been frustrated: there has been a drop in employment in agricultural occupations, continuity of the rural exodus, an increase in the land tenure concentration, a reduction in the number of families engaged in family agriculture and, inclusion of family agriculture produces not in vulnerable situations in the macro-regions South and Central-west instead of poor family farmers in the regions North and Northeast. Similarly, all over Brazil in the ambit of family agriculture, there has been an advance of soybean cultivation to the detriment of food crops like rice, beans and manioc and that includes the states participating in the PNPB, showing that the intended planting of consortia of food crops and agro-energy crops did not take place. Of the PNPB's original goals, the only one satisfactorily achieved was the inclusion of a minimum percentage of biodiesel in commercialized diesel fuel but despite the increase in biodiesel production, dependence on imported diesel is greater than before.

Other studies are needed to assess the PNPB's real contribution to maintaining the above-described situation in the countryside and why the Program was insufficient to achieve the social objectives that were established at the beginning, going beyond the aspects delineated in the present study.

\section{References}

ABIOVE Associação Brasileira das Indústrias de Óleos Vegetais. Estatísticas mensais do complexo soja com dados atualizados até janeiro de 2020 e projeçóes anuais. São Paulo, 2020.

ANP- Agência Nacional do Petróleo, Gás Natural e Biocombustíveis. Anuário Estatístico Brasileiro do Petróleo, Gás Natural e Biocombustíveis: 2019. Rio de Janeiro, 2019.

BARCElOS, M. Uma Política Social na Área de Biocombustíveis? A Trajetória do Programa Nacional de Produção de Biodiesel (PNPB). In: 39ํㅡㄹ ENCONTRO ANUAL DA ANPOCS, Caxambu-MG. Anais... 2015.

BARR, M. R.; VOLPE, R.; KANDIYOTI, R. Liquid biofuels from food crops in transportation A balance sheet of outcomes. Chemical Engineering Science: X, v. 10, p. 1 - 12, 2021.

BERGER, M.; PFISTER, S.; BACH, V., FINKBEINER, M. Saving the Planet's Climate or Water Resources? The Trade-Off between Carbon and Water Footprints of European Biofuels. Sustai- 
nability, v. 7, p. 6665-6683, 2015.

BINI, D. A.; CANEVER, M. D. A dinâmica da área, do rendimento e dos preços sobre o valor da produção do feijão e da soja no Rio Grande do Sul e a dependência temporal entre esses componentes. Ciência Rural, v. 45, n. 6, p. 1139 - 1146, 2015.

BOSI, J. A. O programa nacional de produção e uso de biodiesel e a agricultura familiar. 2015. Thesis (Ph.D. in Environmental Science. Programa de Pós Graduação em Ciência Ambiental (PROCAM), Universidade de São Paulo, São Paulo, 2015.

BRASIL. Decreto no 5.297, de 06 de dezembro de 2004. Dispõe sobre os coeficientes de redução das alíquotas da Contribuição para o PIS/Pasep e da Cofins incidentes na produção e na comercialização de biodiesel, sobre termos e condições para a utilização das alíquotas diferenciadas, e dá outras providencias. Diário Oficial da União. Poder Executivo, Brasília, DF, 07 de dezembro de 2004, seção 1, no 234, p. 2.

BRASIL. Ministério do Desenvolvimento Agrário. Gabinete do Ministro. Instrução Normativa $\mathrm{n}^{\circ} 1$, de 19 de fevereiro de 2009. Dispõe sobre os critérios e procedimentos relativos à concessão, manutenção e uso do selo combustível social. Diário Oficial da União, Brasília, DF, 25 de fev. 2009. p. 37.

BRASIL. Ministério da Agricultura, Pecuária e Abastecimento. Balanço dos 10 anos do Selo Combustível Social. Brasília, DF, 2015.

BRASIL. Secretaria Especial de Agricultura Familiar e do Desenvolvimento Agrário. Balanço do volume e valor comercializados pela agricultura familiar no âmbito do Selo Combustível Social. Brasília, DF, 2019.

CASTRO MUR, D. C. Evolução e sustentabilidade do Programa de Biodiesel: um estudo comparativo entre o Brasil e a Colômbia. 2019. Thesis ( $\mathrm{PhD}$ in Sustainable Development), Universidade de Brasília, Brasília, 2019.

CAVALCANTE FILHO, P. G. A inserção da agricultura familiar na cadeia produtiva do biodiesel. 2020. Dissertação (mestrado em Desenvolvimento Econômico), Instituto de Economia, Unicamp, Campinas - SP. 2020.

CAVALCANTE FILHO, P. G.; BUAINAIN, A. M.; BENATTI, G. S. S. A cadeia produtiva agroindustrial do biodiesel no Brasil: um estudo sobre sua estrutura e caracterização. DRd - Desenvolvimento Regional em debate, v. 9, p. 772-799, 29 out. 2019.

CÉSAR, A. S.; BATALHA, M. O. Biodiesel production from castor oil in Brazil: a difficult reality. Energy Policy, v. 38, p. 4031 - 4039, 2010.

CÉSAR, A. S.; BATALHA, M. O. Brazilian biodiesel: the case of the palm's social projects. Energy Policy, v. 56, p. 165-174, 2013.

CÉSAR, A; S., CONEJERO, M. A., RIBEIRO, E. C. B., BATAlHA, M. O. Competitiveness analysis of "social soybean" in biodiesel production in Brazil. Renewable Energy, v. 133, p. 1147 
$-1157,2019$.

CORRÊA, M. L. M.; PIGNATI, W.A.; PIGNATTI, M.G.; MESQUITA, J.; MACHADO, J.M.H; SOUZA, F.A.N. Alimento ou mercadoria? Indicadores de autossuficiência alimentar em territórios do agronegócio, Mato Grosso, Brasil. Saúde em Debate, v. 43, p. 1070 - 1083, 2019.

COSTA, A. O. A Inserção do Biodiesel na Matriz Energética Nacional: Aspectos Socioeconômicos, Ambientais e Institucionais. 2017. Thesis (PhD in Energy Planning), Programa de Planejamento Energético, COPPE, UFRJ, Rui de Janeiro. 2017.

DE OLIVEIRA, F.C.; LOPES, T.S.A.; PARENTE, V.; BERMANN, C.; COELHO, S.T. The Brazilian social fuel stamp program: Few strikes, many bloopers and stumbles. Renewable and Sustainable Energy Reviews, v. 102, p. 121 - 128, 2019.

DIEESE - Departamento Intersindical de Estatística e Estudo Socioeconômico. O mercado de trabalho assalariado rural brasileiro. Estudos e Pesquisas, São Paulo, n. 74, 2014.

EPE - Empresa de Pesquisa Energética. Balanço Energético Nacional 2019. Rio de Janeiro, 2019.

FREITAS, R. C. 5 problemas da mamona. BiodieselBr, Curitiba, 15 mar. 2010.

HOEKMAN, S. K.; BROCH, A.; LIU, X. Environmental implications of higher ethanol production and use in the U.S.: A literature review. Part I - Impacts on water, soil, and air quality. Renewable and Sust. Energy Reviews, v. 81, p. 3140-3158, 2018.

HOFFMANN, R.; JESUS, J. G. Desigualdade na agricultura brasileira: renda e posse da terra. IN: NAVARRO, Z. (Org.). A economia agropecuária do Brasil: a grande transformação. São Paulo: Editora Baraúna, 2020. p. 123 - 175.

HOLANDA, A. Biodiesel e inclusão social. Câmara dos Deputados, Coordenação de Publicações, Brasília, 2004.

IBGE - INSTITUTO BRASILEIRO DE GEOGRAFIA E ESTATÍSTICA. Censo Agropecuário 2006. IBGE, Brasília, DF, 2007.

IBGE - INSTITUTO BRASILEIRO DE GEOGRAFIA E ESTATÍSTICA. Censo Agropecuário 2017. IBGE, Brasília, DF, 2020a.

IBGE - INSTITUTO BRASILEIRO DE GEOGRAFIA E ESTATÍSTICA. Censo Demográfico 2010. Brasília, DF, 2011.

IBGE - INSTITUTO BRASILEIRO DE GEOGRAFIA E ESTATÍSTICA. Pesquisa Nacional por Amostra de Domicílio Contínua. Brasília, DF, 2020 b.

IBGE - INSTITUTO BRASILEIRO DE GEOGRAFIA E ESTATÍSTICA. Pesquisa Nacional por Amostra de Domicílio. Brasília, DF, 2015. 
IBGE - INSTITUTO BRASILEIRO DE GEOGRAFIA E ESTATÍSTICA. Produção Agrícola Municipal 2018. IBGE, Brasília, DF, 2021.

IPEA - Instituto de Pesquisa Econômica Aplicada. Biodiesel no Brasil: Desafios das políticas públicas para a dinamização da produção. Comunicados do IPEA, n 137, Brasília, DF, 2012.

LEITE J. D. B.; JUSTINO, F.B.; SILVA J. V.; FLORIN M.; VAN ITTERSUM, M. Socioeconomic and environmental assessment of biodiesel crops on family farming systems in Brazil. Agricultural Systems, v. 133, p. 22 -34, 2015.

LOCATEL, C. D; AZEVEDO, F. F. Desenvolvimento rural, política nacional de biocombustíveis e o mito da inclusão social no campo brasileiro. In: Colóquio Internacional de Geocrítica, 10. Barcelona. Anais... 2008.

MEDINA, H. Governo enterra de vez biodiesel feito só com mamona. Folha de São Paulo, São Paulo, 29 jul. 2008.

NERY DO PRADO, J. Estudo sobre o Programa Nacional de Produção e Uso do Biodiesel (PNPB): uma análise sobre os munícipios produtores de soja e as cooperativas de agricultura familiar. 2015. Thesis (PhD in Energy). Faculdade de Economia, Universidade Federal de Juiz de Fora, Juiz de Fora, Minas Gerais, 2015.

PIRAS, S.; WESZ, V.J.; Jr.; GHINOI, S. Soybean Expansion, Environment, and Human Development: An Analysis across Brazilian Municipalities. Sustainability, v. 2021, v. 13, p. 1 - 20, 2021.

QUEIROZ, T. L. B.; GARCIA, M.F. Controle da agricultura e produção de energia: limites do PNPB na Paraíba. IN: Ramos Filho, E.S.; Santos, A. R.; Santos, L.R.S. (Org.). Agrocombustíveis, trabalho e resistências territoriais. São Paulo: Outras Expressões, 2015. p. 79 - 96.

RAMOS FILHO, E. S. A expansão dos agrocombustíveis e os impactos socioterritoriais nos assentamentos de reforma agrária em Sergipe - Brasil. IN: RAMOS FILHO, E. S.; SANTOS, A. R.; SANTOS, L. R. S. (Org.). Agrocombustíveis, trabalho e resistências territoriais. São Paulo: Outras Expressões, 2015. p. 17 - 54.

RESENDE, R. M. M. R. O Programa Nacional para Produção e Uso do Biodiesel na realidade da agricultura familiar de Rio Verde-GO. 2015. Dissertação (mestrado em Agronegócio), Escola de Agronomia, Universidade Federal de Goiás. Goiânia. 2015.

RIBEIRO, D. D.; DIAS, M. S. Efeitos do Programa Nacional de Produção e Uso de Biodiesel no território camponês em assentamento rural. Interações (Campo Grande), Campo Grande, v. 17, n. 1, p. 15-21, 2016.

RODRIGUES, A. C. C. Policy, regulation, development and future of biodiesel industry in Brazil. Cleaner Eng. and Technology, v. 4. 2021.

SAMPAIO, R. M. Biodiesel no Brasil: capacidades estatais, P\&D e inovação na Petrobras Biocombustíveis. 2017. Thesis (PhD in Scientific and Technological Policy), Instituto de Geociências, Universidade Estadual de Campinas, Campinas - SP. 2017. 
SANTANA, G. C. S.; MARTINS, P. F.; DA SILVA, N. L; BATISTELLA, C. B.; MACIEL FILHO, R.; WOLF MACIEL, M. R. Simulation and cost estimate for biodiesel production using castor oil. Chemical Eng. Research and Design, v. 88, p. 626-632, 2010.

SILVA E SILVA, F.; GRASEL, D.; MERTENS, F. Participação da agricultura familiar no Programa Nacional de Biodiesel. Revista de Política Agrícola, v. 26, n. 1, ago. 2017.

SILVA, M. A. M. Produção de alimentos e agrocombustíveis no contexto da nova divisão mundial do trabalho. Revista Pegada, Presidente Prudente, São Paulo, v. 9, n. 1, p. 63-80, jun. 2008.

SILVA, M. E. S. A Política pública do biodiesel e os desafios para a inclusão dos diferentes estilos de agricultura familiar no mercado dos biocombustíveis no Brasil. 2019. Thesis ( $\mathrm{PhD}$ in Sociaologydoutorado em Sociologia). Programa de Pós-graduação em Sociologia, Instituto de Filosofia e Ciências Humanas, UFRGS, Porto Alegre. 2019.

SILVA, M. E. S. Da terra prometida à terra do abandono: o legado do Programa do biodiesel no sertão do Piauí. REVES, v. 1, n. 1, p. 0001-0013, 2 maio 2018.

STATTMAN, S. L.; MOL, A. P. J. Social sustainability of Brazilian biodiesel: The role of agricultural cooperatives. Geoforum, v. 54, p. 282 - 294, 2014.

VASILEA, A. J.; ANDREEAB, I. R.; POPESCUC, G. H.; LVIRAB, N.; MARIAN, Z. Implications of agricultural bioenergy crop production and prices in changing the land use paradigmThe case of Romania. Land Use Policy, v. 50, p. 399-407, 2016.

ZAMAN, K.; AWAN, U.; ISLAM, T.; PAIDI, R.; HASSAN, A.; ABDULLAH, A. Econometric applications for measuring the environmental impacts of biofuel production in the panel of worlds largest region. Renewable and Sust. Energy Reviews, v. 81, p. 3140-3158, 2018. 
Gean Claudio de Souza Santana

$\varangle$ gean@uefs.br

ORCiD: https://orcid.org/0000-0003-2721-359
Submitted on: 23/02/2019

Accepted on: 02/09/2021

2021;24e:00882

How to cite: SANTANA, G. C. S. As metas do Programa Nacional de Biodiesel: entre o planejado e o realizado. Ambiente $\boldsymbol{\&}$ Sociedade. São Paulo, v. 24, p. 1-20, 2021. 


\title{
As metas do Programa Nacional de Biodiesel: entre o planejado e o realizado
}

\author{
Gean Claudio de Souza Santana
}

São Paulo. Vol. 24, 2021

Artigo Original

\begin{abstract}
Resumo: Este trabalho avaliou se as principais metas estabelecidas pelo Programa Nacional de Produção e Uso do Biodiesel (PNPB) foram alcançadas entre 2004 e 2018. Para isso, foram utilizados relatórios e pesquisas elaborados por órgãos públicos e produtores de soja. Os resultados apresentados por este trabalho revelam que as expectativas de melhoria nas condições de vida no meio rural, por conta da implementação do PNPB, foram frustradas: houve perdas de empregos em ocupações agrícolas, continuidade do êxodo rural, aumento da concentração fundiária, redução no contingente de agricultores familiares, não inclusão de agricultores familiares pobres e das Regiões Norte e Nordeste. Das metas pretendidas pelo PNPB, apenas o percentual mínimo do biodiesel ao diesel foi alcançado satisfatoriamente, mas a dependência do diesel importado aumentou, mesmo com o desenvolvimento da produção do biodiesel.
\end{abstract}

Palavras-chave: Biodiesel; biocombustíveis; agricultores familiares; Selo Combustível Social; PNPB.

Como citar: SANTANA, G. C. S. As metas do Programa Nacional de Biodiesel: entre o planejado e o realizado. Ambiente $\&$ Sociedade. São Paulo, v. 24, p. 1-20, 2021. 


\title{
Los objetivos del Programa Nacional de Biodiesel: entre lo planeado y lo ejecutado
}

\author{
Gean Claudio de Souza Santana
}

São Paulo. Vol. 24, 2021

Artículo original
Resumen: En este trabajo se evaluó si las principales metas establecidas por el Programa Nacional de Producción y Uso de Biodiesel (PNPB) se alcanzaron entre 2004 y 2018. Para ello, se utilizaron informes e investigaciones elaboradas por organismos públicos y productores de soja. Los resultados presentados por este trabajo revelan que las expectativas de mejora de las condiciones de vida en las zonas rurales, debido a la implementación del PNPB, se vieron frustradas: hubo pérdidas de empleo en ocupaciones agrícolas, continuidad del éxodo rural, aumento de la concentración de la tierra, reducción de la contingente de agricultores familiares, no inclusión de agricultores familiares pobres de las regiones Norte y Nordeste. De las metas que pretendía la PNPB, solo se alcanzó satisfactoriamente el porcentaje mínimo de biodiesel a diesel, pero la dependencia del diesel importado aumentó, aun con el desarrollo de la producción de biodiesel.

Palabras-clave: Biodiesel; biocombustibles; agricultores familiares; sello social de combustible; PNPB.

Como citar: SANTANA, G. C. S. Los objetivos del Programa Nacional de Biodiesel: entre lo planeado y lo ejecutado. Ambiente $\mathbb{\&}$ Sociedade. São Paulo, v. 24, p. 1-20, 2021.

DOI: http://dx.doi.org/10.1590/1809-4422asoc20200088r2vu2021L5AO 